\title{
Development and validation of a high performance liquid chromatography method to determine linezolid concentrations in pig pulmonary tissue
}

\author{
Laura Guerrero ${ }^{1}$, Pilar Martínez-Olondris ${ }^{2}$, \\ Montserrat Rigol ${ }^{3}$, Mariano Esperatti ${ }^{2}$, Cristina \\ Esquinas $^{2}$, Néstor Luque ${ }^{2}$, Raquel Piñer ${ }^{2}$, Antoni \\ Torres $^{2}$ and Dolors Soy ${ }^{1, *}$ \\ ${ }^{1}$ Pharmacy Service, Hospital Clínic de Barcelona, Institut \\ d'Investigacions Biomèdiques August Pi i Sunyer \\ (IDIBAPS), Universidad de Barcelona, Spain \\ ${ }^{2}$ Pneumology Service, Institut Clínic del Tòrax, Hospital \\ Clínic de Barcelona, Institut d'Investigacions Biomèdiques \\ August Pi i Sunyer (IDIBAPS), Universidad de Barcelona, \\ Spain \\ ${ }^{3}$ Cardiology Service, Institut Clínic del Tòrax, Hospital \\ Clínic de Barcelona, Institut d'Investigacions Biomèdiques \\ August Pi i Sunyer (IDIBAPS), Universidad de Barcelona, \\ Spain
}

\begin{abstract}
Background: Linezolid is the first synthetic compound of a new group of antimicrobials, the oxazolidinones, which inhibit protein synthesis. It shows a broad spectrum of activity against Gram positive organisms. With respect to its pharmacokinetics, linezolid shows a relatively high volume of distribution and good penetration into inflammatory fluids, bone, fat and muscle.

Methods: A reversed-phase isocratic high-performance liquid chromatographic method for linezolid analysis in piglet pulmonary tissue is described. Tissue samples and controls were prepared in $1 \times$ TBE $(1 \mathrm{M}$ Tris, $0.9 \mathrm{M}$ boric acid, 0.01 M EDTA). The mobile phase consisted of $20 \%$ ultrafiltered water and $80 \%$ of (A) $15 \mathrm{mM}$ potassium monohydrogen phosphate buffer $(\mathrm{pH}=5)$ with (B) acetonitrile $(80 \% / 20 \%$; $\mathrm{v} / \mathrm{v})$. Samples were homogenized and precipitated with $\mathrm{HClO}_{4} 3 \%(1 / 1, \mathrm{v} / \mathrm{v})$. The injection volume was $100 \mu \mathrm{L}$. Ofloxacin was used as an internal standard.

Results: The assay was linear over a linezolid concentration range: $1.6-100 \mu \mathrm{g} / \mathrm{mL}$. The method provided good validation data $(\mathrm{n}=15)$ : inaccuracy $(3.6 \%)$, intra and inter-day variability ( $4.2 \%$ and $5.2 \%$, respectively), recovery $(91.8 \%)$, limit of detection $(0.8 \mu \mathrm{g} / \mathrm{mL})$ and quantitation $(1.6 \mu \mathrm{g} / \mathrm{mL})$ and acceptable stability within $24 \mathrm{~h}$ in the auto-sampler.
\end{abstract}

*Corresponding author: Dolors Soy, PharmD, PhD, Pharmacy Service, Hospital Clínic de Barcelona, C/Villarroel, 170 - 08036, Barcelona, Spain

Phone: +3493 2275479, Fax: +34 932275457 ,

E-mail: dsoy@clinic.ub.es

Received July 13, 2009; accepted November 11, 2009;

previously published online February 1, 2010
Conclusions: The method offers a fast and simple approach to determine linezolid in pulmonary tissue which could be of use in pharmacokinetic studies.

Clin Chem Lab Med 2010;48:391-8.

Keywords: analytics; chromatography; high pressure liquid; linezolid; tissue; validation.

\section{Introduction}

Linezolid (LNZ) (1) is the first synthetic compound of a new group of antimicrobial drugs, the oxazolidinones (Figure 1) which inhibit protein synthesis early in translation. It shows a broad spectrum of activity against Gram positive organisms including methicillin resistant Staphylococcus aureus (MRSA), penicillin resistant pneumococci and vancomycin resistant Enterococcus faecalis and Enterococcus faecium.

After a dose of $600 \mathrm{mg}$ twice a day, the maximum serum concentration is $\sim 20 \mathrm{mg} / \mathrm{L}$. With respect to its pharmacokinetics (PK), linezolid shows a relatively high volume of distribution (40-50 L) and good penetration into inflammatory fluids, bone, fat and muscle (2).

It is well known that antibiotic concentrations at the site of the infection differ greatly from those in plasma. Drug penetration varies depending on the drug, the tissue involved and the infection. Also, protein binding, physical-chemical drug properties, lipid solubility, etc. have some influence on the amount of drug that is able to reach peripheral tissue/ compartments. Data on drug penetration for the latest antimicrobial drugs, such as ertapenem, tigecycline, telithromycin or linezolid have recently been published (3-6). Thus, in localized infections including lung infection, meningitis, endocarditis or osteomyelitis, it is extremely valuable to know what fraction of the free drug will be able to cross membranes and barriers and reach the site of the infection. Hence, many reports in the literature have been performed on drug penetration into different tissues. Examples include drug penetration into the epithelial lining fluid (ELF) (7-10) and lung tissue (11).

High performance liquid chromatography (HPLC) can be considered an adequate technique (12) for determining linezolid in pulmonary tissue. The sensitivity and precision of HPLC and its applicability to a wide variety of compounds has led to its use in clinical laboratories for monitoring of a variety of therapeutic agents in hospital settings, and pharmacokinetic and metabolism studies $(13,14)$. 


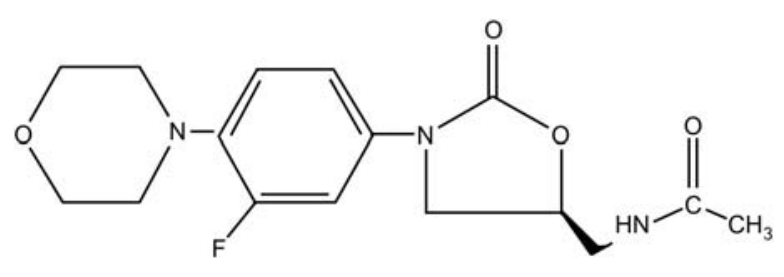

Figure 1 Chemical structure of linezolid.

The goal of this study was to develop a new assay to quantify linezolid in lung tissue obtained from a model of pneumonia in mechanically ventilated piglets treated with linezolid.

\section{Materials and methods}

\section{Reagents}

Linezolid and ofloxacin, the internal standard (IS), were obtained from Pfizer, S.A. (Madrid, Spain) and Riedel-deHaën SigmaAldrich Laborchemikalien GmbH (Seelze, Germany), respectively. Perchloric acid $70 \%$ PRS and potassium phosphate dibasic, ACS reagent, $\geq 98 \%$ were purchased from Panreac (Barcelona, Spain) and Sigma-Aldrich (Steinheim, Germany). Acetonitrile gradient 240/far-UV-HPLC grade was acquired from Sharlau, S.A. (Barcelona, Spain) and the $10 \times$ TBE Buffer Ultrapure (1 M Tris, $0.9 \mathrm{M}$ boric acid, 0.01 M EDTA) from Invitrogen (Paisley, Scotland).

\section{Instrumentation}

HPLC was performed using an Agilent 1100 liquid chromatography system (Agilent Technologies Spain, S.L., Madrid, Spain) consisting of a vacuum degasser, a gradient pump, an auto sampler and variable wavelength ultraviolet (UV) detector. Data acquisition was performed using the appropriate software (Agilent Chemstation Rev.B.03.01) for signal treatment.

\section{High-performance liquid chromatography}

The HPLC method used in this study is based on the method proposed by Tobin et al. to determine linezolid in plasma (15).

In the present study, the stationary phase was a silica based column Novapak ${ }^{\circledR} \mathrm{C}_{18}(150 \times 3.9 \mathrm{~mm})$ with pre-column from Waters Corporation (Milford, MA, USA). The mobile phase consisted of $20 \%$ ultrafiltered water and $80 \%$ of (A) $15 \mathrm{mM}$ potassium monohydrogen phosphate buffer $(\mathrm{pH}=5)$ with (B) acetonitrile $(80 \% / 20 \%$; $\mathrm{v} / \mathrm{v})$. The flow rate was fixed to $0.7 \mathrm{~mL} / \mathrm{min}$ and the injection volume to $100 \mu \mathrm{L}$. UV absorbance detection was set at $254 \mathrm{~nm}$.

\section{Drug analysis and calibration}

Calibration curves were constructed by cutting small pieces of control lung tissue (from pigs without antibiotic treatment). The observed peak-area ratio method with reference to the IS was applied to assess drug concentration.

Calculation of the unknown linezolid concentration in tissue samples was performed using the linear regression equation of the peak area ratio against the concentration ratio for the calibration curve. Correction for the tissue experimental weight was taken into account. A standard equation to normalize weights of pulmonary tissues and the extracted volume after the homogenization process was used Eq. [1] (16).

$$
\begin{aligned}
\left(\left(\left(\mathrm{A}_{\mathrm{LNZ}} / \mathrm{A}_{\text {Oflox }}\right) / \mathrm{g}_{\text {exp }}\right) \times \mathrm{V}_{\text {Real }}\right)= & \mathrm{n}+\mathrm{m} \times\left[\left(\left(\mathrm{LNZ}_{\text {theor }}\right) /\left(\mathrm{Oflox}_{\text {theor }}\right)\right)\right. \\
& \left.\times\left(\mathrm{g}_{\text {exp }} / \mathrm{g}_{\text {theor }}\right) \times \mathrm{V}_{\text {Real }}\right]
\end{aligned}
$$

where: $\mathrm{A}_{\mathrm{LNZ}}$ : linezolid area $(\mathrm{mAu}) ; \mathrm{A}_{\mathrm{Oflox}}$ : ofloxacin area $(\mathrm{mAu})$; $\left[\mathrm{LNZ}_{\text {theor }}\right]$ : linezolid theoretical concentration $(\mu \mathrm{g} / \mathrm{mL}) ;\left[\mathrm{Oflox}_{\text {theor }}\right]$ : ofloxacin theoretical concentration $(\mu \mathrm{g} / \mathrm{mL}) ; g_{\text {exp }}$ : pulmonary pig tissue experimental weight $(\mathrm{g})$; $\mathrm{g}_{\text {theor }}$ : pulmonary pig tissue theoretical weight $(0.5 \mathrm{~g})$; $\mathrm{V}_{\text {Real }}$ : real volume $(\mathrm{L})$; $\mathrm{m}$ : slope; $\mathrm{n}$ : ordinate at linezolid concentrations equals 0 .

\section{Sample collection}

Samples were obtained from a model of pneumonia, developed in mechanically ventilated piglets that were treated with linezolid. All tissue samples (standards, quality controls and experimental) were freshly cut into pieces of $\sim 0.5 \mathrm{~g}$, and kept frozen at $-40^{\circ} \mathrm{C}$ until analysis. Prior to analysis, they were homogenized in a manual homogenator supplied by ANORSA (Barcelona, Spain).

\section{Preparation of standard and quality controls}

Buffer solution ( $1 \times$ TBE buffer) A $1 \times$ TBE buffer solution was prepared by dilution of $10 \times \mathrm{TBE}(1 \mathrm{M}$ Tris, $0.9 \mathrm{M}$ boric acid, $0.01 \mathrm{M}$ EDTA) in ultrapure water (1/10). This solution was maintained at room temperature.

Stock standard and quality control solutions The same stock solution containing $2 \mathrm{mg} / \mathrm{mL}$ of linezolid was used to prepare both standard and quality control material. From this stock solution, three levels of quality control (working standard solutions) at $3.1 \mu \mathrm{g} / \mathrm{mL}$, $25 \mu \mathrm{g} / \mathrm{mL}$ and $100 \mu \mathrm{g} / \mathrm{mL}$ of linezolid were prepared by appropriate dilutions in $1 \times$ TBE. These dilutions were spiked with ofloxacin to achieve a final concentration of $100 \mu \mathrm{g} / \mathrm{mL}$.

Standard preparation Tissue control specimens $(0.5 \mathrm{~g})$ were spiked with the appropriate volume of a stock linezolid solution to attain several standard samples of different linezolid concentrations, and with $70 \mu \mathrm{L}$ of ofloxacin standard solution $(500 \mu \mathrm{g} / \mathrm{mL})$. Finally, $262.5 \mu \mathrm{L}$ of $1 \times$ TBE was added to obtain a final volume of $350 \mu \mathrm{L}$ for standards, quality control and unknown samples. These standards were homogenized for $30 \mathrm{~s}$ and then extracted and precipitated with $350 \mu \mathrm{L}$ of $\mathrm{HClO}_{4} 3 \%(1 / 1, v / v)$. Next, they were centrifuged at $8000 \times g$ for $10 \mathrm{~min}$. Finally, $100 \mu \mathrm{L}$ of the supernatant was injected into the chromatographic system.

Sample preparation All tissue samples $(0.5 \mathrm{~g})$ were added with $350 \mu \mathrm{L}$ of $1 \times \mathrm{TBE}$ spiked with the IS at $100 \mathrm{mg} / \mathrm{L}$. These specimens were homogenized for $30 \mathrm{~s}$, extracted and precipitated with $350 \mu \mathrm{L}$ of $\mathrm{HClO}_{4} 3 \%(1 / 1, \mathrm{v} / \mathrm{v})$. Afterwards, they were centrifuged at $8000 \times g$ for $10 \mathrm{~min}$ and $100 \mu \mathrm{L}$ of the supernatant was injected into the chromatographic system.

\section{Validation criteria}

In accordance with the USA Food and Drug Administration's Guidance for Industry Bioanalytical Method Validation, and the European Agency for the evaluation of Medicinal Products' Guideline on Validation of Analytical Procedures, the following seven criteria were evaluated: linearity, accuracy, precision, recovery, limits of 
detection and quantitation and stability (17-21). In addition, in this study, quality control samples were analyzed in parallel to establish the suitability of the method.

Linearity Calibration curves were constructed by cutting small pieces of control lung tissue (from pigs without antibiotic treatment). A seven-point standard curve of linezolid was constructed by drawing the ratio between the peak area of linezolid and the peak area of ofloxacin vs. the ratio between linezolid concentration and ofloxacin concentration. The concentration of linezolid ranged from 1.6 to $100 \mu \mathrm{g} / \mathrm{mL}$.

Calculation of the unknown linezolid concentration in tissue samples was performed using the linear regression equation of the peak area ratio against the concentration ratio for the calibration curve. Correction for the tissue experimental weight was taken into account. A standard equation to normalize the weights of pulmonary tissues and the extracted volume after the homogenization process was used Eq. [1] (16).

Linearity was assessed using Pearson's coefficient (r), the coefficient of correlation $\left(\mathrm{r}^{2}\right)$, and the $\left(\mathrm{t}_{\text {student }}\right)$ for the slope and Pearson's coefficient.

Accuracy and precision Accuracy of an analytical method is defined as the agreement between results obtained by the analytical method to the true value. Precision describes the degree of the similarity (17). The accuracy of the method was performed using a recovery study with 15 drug-spiked samples at three concentrations $(100,25$ and $3.1 \mu \mathrm{g} / \mathrm{mL})$ measured in one run performed in a single day. This allowed us to determine intra-day precision and accuracy.

Analysis of the same drug concentrations over three consecutive days was performed to determine inter-day precision. Accuracy and precision were calculated as follow Eqs. [2, 3], respectively:

$\% \mathrm{E}_{\mathrm{R}}=\left([\mathrm{LNZ}]_{\exp }-\left[\mathrm{LNZ}_{\text {theor }}\right]\right) /\left[\mathrm{LNZ}_{\text {theor }}\right] \times 100$

where: $\mathrm{E}_{\mathrm{R}}$ : accuracy; $\left[\mathrm{LNZ}_{\text {theor }}\right]$ : linezolid theoretical concentration $(\mu \mathrm{g} / \mathrm{mL})$; $\left[\mathrm{LNZ}_{\text {exp }}\right]$ : linezolid experimental concentration $(\mu \mathrm{g} / \mathrm{mL})$.

$\% \mathrm{CV}=\left(\mathrm{SD} / \mathrm{X}_{\mathrm{ave}}\right) \times 100$

where: $\mathrm{CV}$ : coefficient of variation; $\mathrm{SD}$ : standard deviation; $\mathrm{X}_{\mathrm{ave}}$ : average concentration of drug $(\mu \mathrm{g} / \mathrm{mL})$.

For the analysis to be considered acceptable, no more than onethird of the quality control tests were allowed to deviate from the nominal concentration by more than $15 \%$, and at least $50 \%$ of the results from each quality control sample had to be within $15 \%$ of the nominal concentration.

Recovery Recovery was determined by comparison of the analysis between samples with known concentrations of the analyte and extracts, obtained after homogenization of a piece of control pulmonary tissue, spiked with linezolid (plus the IS) at the same concentrations as those prepared in the quality controls. Recovery was calculated as follows:

$\mathrm{R}(\%)=\left(\mathrm{A}_{\text {LNZ Exp }} / \mathrm{A}_{\text {Oflox Exp }}\right) /\left(\mathrm{A}_{\text {LNZ Cont }} / \mathrm{A}_{\text {Oflox Cont }}\right) \times 100$

where: $A_{\text {LNZ Exp }}$ : linezolid area of the spiked extract $(m A u)$; $\mathrm{A}_{\text {Oflox Exp }}$ : ofloxacin area of the spiked extract (mAu); $\mathrm{A}_{\mathrm{LNZ} \text { Cont: }}$ : linezolid area of the control (mAu); $\mathrm{A}_{\text {Oflox Cont }}$ ofloxacin area of the control $(\mathrm{mAu})$.
Limit of detection (LOD) Several samples with known concentrations of linezolid (plus the IS) were prepared fresh. The LOD was established by visual evaluation of the minimum concentration at which the linezolid signal can be reliably detected.

Lower limit of quantitation (LLOQ) The LLOQ is the lowest amount of analyte in a sample which can be determined with precision and accuracy that is not $< \pm 20 \%$. This parameter was established by analysis of seven samples with known concentrations of linezolid (linearity assay). Bias $\left(\mathrm{E}_{\mathrm{R}} \%\right)$ and precision $(\% \mathrm{CV})$ at the LLOQ were evaluated by a recovery study of five replicates.

Freeze and thaw stability Linezolid stability was determined after three freeze $\left(-40^{\circ} \mathrm{C}\right)$ and thaw cycles of three drug-spiked samples with concentrations of $100 \mu \mathrm{g} / \mathrm{mL}, 25 \mu \mathrm{g} / \mathrm{mL}$, and 3.1 $\mu \mathrm{g} / \mathrm{mL}$, all measured in one run performed in 1 day.

Post-preparative stability The stability of processed samples at room temperature, including the resident time in the auto-sampler was determined using three aliquots with different concentrations. We compared the results obtained with fresh sample with those obtained with these same samples after $24 \mathrm{~h}$ (or real work time) in the auto-sampler.

The non-parametric Wilcoxon test was used to compare results and $\mathrm{p}<0.05$ was used for statistical significance. Statistical analysis was performed with SPSS 15.0 for Windows (SPSS Inc., Chicago, IL, USA).

\section{Pig pulmonary tissue samples}

Lung tissue samples from a piglet model of pneumonia (22) were analyzed in order to determine linezolid concentrations. Animals were treated with $10 \mathrm{mg} / \mathrm{kg}$ (mean dose: $350 \mathrm{mg} / 12 \mathrm{~h}$ ) of linezolid twice daily (1) for $96 \mathrm{~h}$, or until death. At euthanasia (at least $12 \mathrm{~h}$ after the last dose of linezolid), pulmonary tissue was obtained from several lung segments and kept frozen at $-40^{\circ} \mathrm{C}$ until analysis. Tissue specimens $(0.5 \mathrm{~g})$ were spiked with $70 \mu \mathrm{L}$ of ofloxacin standard solution $(500 \mu \mathrm{g} / \mathrm{mL})$. Finally, $280 \mu \mathrm{L}$ of $1 \times \mathrm{TBE}$ was added to obtain a final volume of $350 \mu \mathrm{L}$ for all samples. These samples were homogenized for $30 \mathrm{~s}$, extracted and precipitated with $350 \mu \mathrm{L}$ of $\mathrm{HClO}_{4} 3 \%(1 / 1, \mathrm{v} / \mathrm{v})$. Afterwards, samples were centrifuged at $8000 \times g$ for $10 \mathrm{~min}$. Finally, $100 \mu \mathrm{L}$ of the supernatant was injected into the chromatographic system.

\section{Results}

\section{HPLC assay}

Linezolid and the IS were quantitatively extracted from pulmonary tissue after homogenation and precipitation. Under the experimental conditions described in the previous section (Materials and methods: High-performance liquid chromatography), linezolid and the IS were eluted within the retention windows of 11-12 $\mathrm{min}$ and 5-6 min, respectively. Representative chromatograms of blank tissue and quality control samples are shown in Figure 2A, B.

\section{Assay validation}

The correlation between drug concentration and peak area was excellent for TBE in tissue across the concentration 

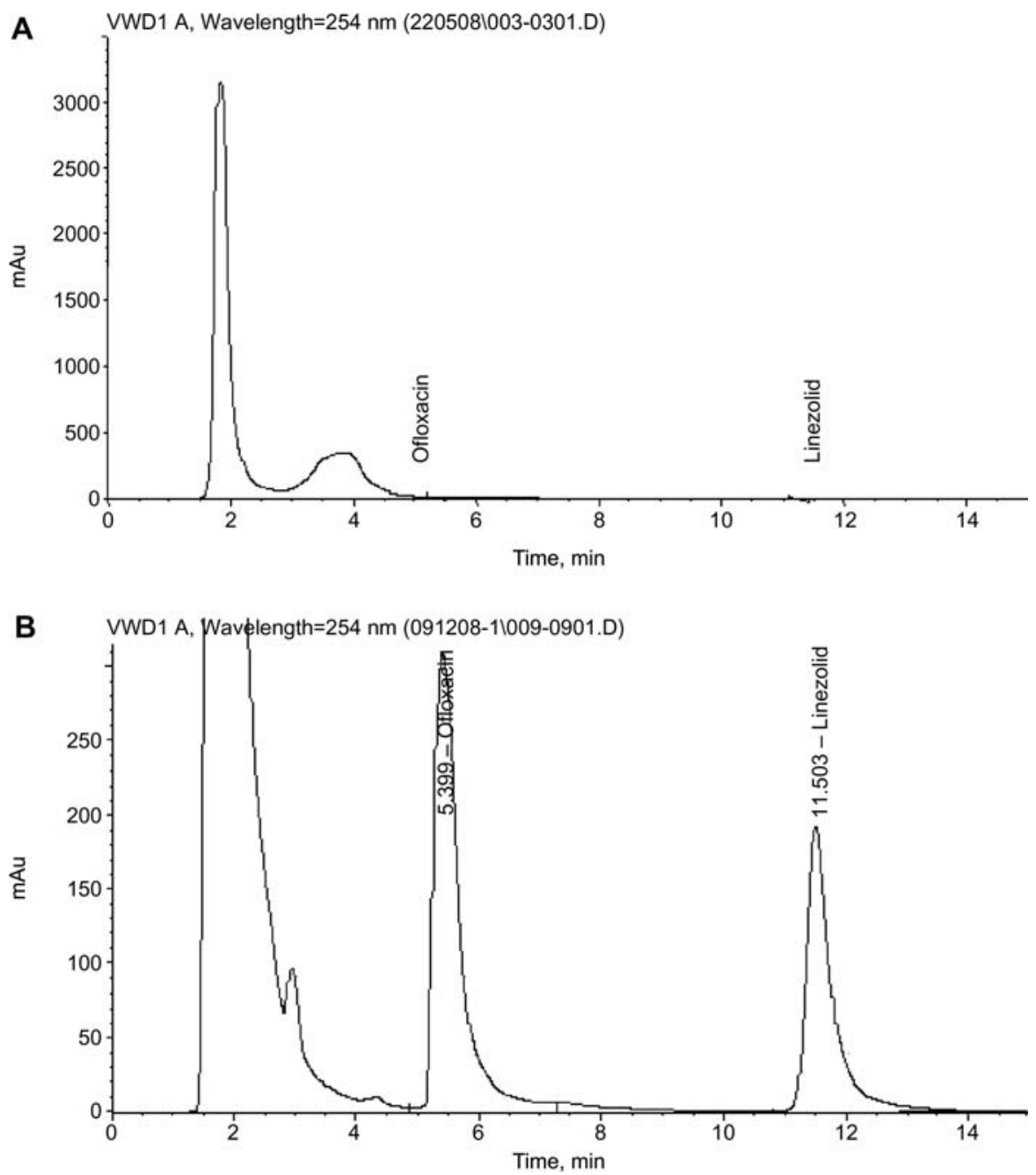

Figure 2 Chromatogram of (A) blank lung tissue and (B) spiked control linezolid tissue $(50 \mu \mathrm{g} / \mathrm{mL})$.

range studied (from $1.6 \mu \mathrm{g} / \mathrm{mL}$ to $100 \mu \mathrm{g} / \mathrm{mL}$ ). Pearson coefficient ( $r)$ and coefficient of correlation $\left(r^{2}\right)$ were calculated: $r=0.9978$ and $r^{2}=0.9958$. The regression line $(y=0.0052+2.4395 x)$ was not significantly different from the unity line $(\mathrm{p}>0.05)$. Inaccuracy, precision and recovery were assessed by analyzing quality control samples. Results are shown in Table 1.

The LOD was $0.8 \mu \mathrm{g} / \mathrm{mL}$. The LLOQ was $1.6 \mu \mathrm{g} / \mathrm{mL}$ (bias and precision: $\mathrm{E}_{\mathrm{R}} \%=-7.6 \%$ and $\mathrm{CV} \%=7.8 \%$, respec- tively). Typical chromatograms of the LLOQ are shown in Figure 3A, B.

The mean recovery, calculated from the ratio of the areas between linezolid and the IS (A.LNZ/A.Oflox), remained fairly constant $(93.6 \%, 92.5 \%$ and $89.5 \%)$ at three different concentrations of linezolid $(100,25$ and $3.1 \mu \mathrm{g} / \mathrm{mL}$, respectively). This confirms the use of ofloxacin as an IS.

Results from the stability analysis revealed no loss of linezolid after three freeze $\left(-40^{\circ} \mathrm{C}\right)$ and thaw cycles. Results are

Table 1 Results for validation parameters.

\begin{tabular}{lccc}
\hline Linezolid & $3.1 \mu \mathrm{g} / \mathrm{mL}$ & $25 \mu \mathrm{g} / \mathrm{mL}$ & $100 \mu \mathrm{g} / \mathrm{mL}$ \\
\hline Intra-day inaccuracy $\left(\mathrm{E}_{\mathrm{R}} \%\right)(\mathrm{n}=5)$ & -5.1 & -7.5 & 2.1 \\
Inter-day inaccuracy $\left(\mathrm{E}_{\mathrm{R}} \%\right)(\mathrm{n}=15)$ & -4.8 & -9.7 & 3.7 \\
Intra-day precision $(\mathrm{CV} \%)(\mathrm{n}=15)$ & 5.1 & 4.8 & 2.5 \\
Inter-day precision $(\mathrm{CV} \%)(\mathrm{n}=15)$ & 6.6 & 6.2 & 2.8 \\
\hline
\end{tabular}



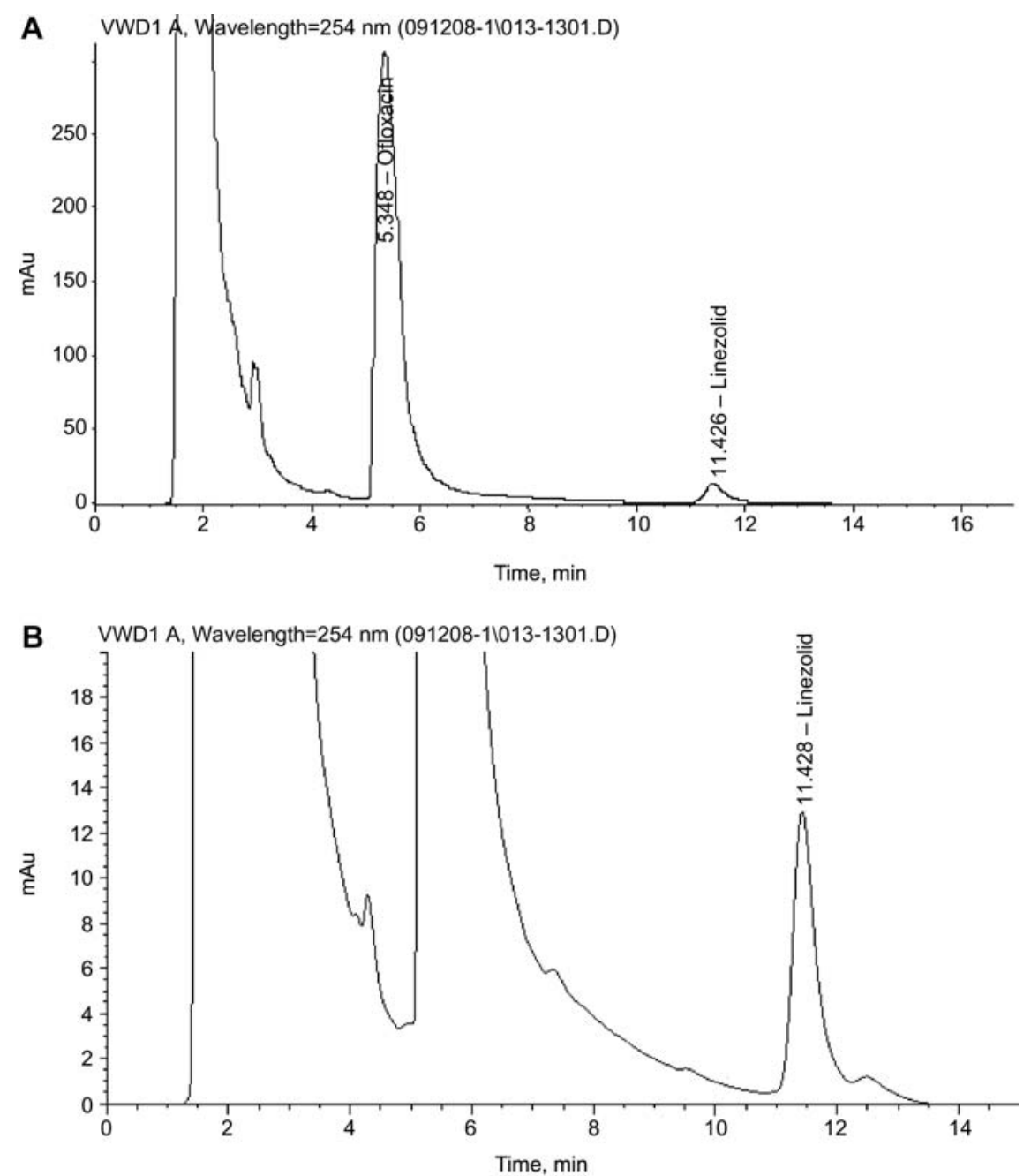

Figure 3 Chromatogram of (A) lower limit of quantification (LLOQ) including a zoom of the region of interest (B).

shown in Table 2. The IS (ofloxacin) showed degradation after $3 \mathrm{~h}$ at room temperature. Thus, quantification $\left(\mathrm{A}_{\mathrm{LNZ}} /\right.$ $\mathrm{A}_{\text {Oflox }}$ ) was not possible (Table 3). However, no significant differences were seen in the linezolid signal $\left(\mathrm{A}_{\mathrm{LNZ}}\right)$ after maintaining linezolid samples at room temperature for $24 \mathrm{~h}$ : $\left(\mathrm{A}_{\mathrm{LNZ}}\right)_{0 \mathrm{~h}}=10,331 \mathrm{mAu}$ vs. $\left(\mathrm{A}_{\mathrm{LNZ}}\right)_{24 \mathrm{~h}}=9910 \mathrm{mAu}$ at 100 $\mu \mathrm{g} / \mathrm{mL} ;\left(\mathrm{A}_{\mathrm{LNZ}}\right)_{0 \mathrm{~h}}=1623 \mathrm{mAu}$ vs. $\left(\mathrm{A}_{\mathrm{LNZ}}\right)_{24 \mathrm{~h}}=1538 \mathrm{mAu}$ at $25 \mu \mathrm{g} / \mathrm{mL}$ and $\left(\mathrm{A}_{\mathrm{LNZ}}\right)_{0 \mathrm{~h}}=225 \mathrm{mAu}$ vs. $\left(\mathrm{A}_{\mathrm{LNZ}}\right)_{24 \mathrm{~h}}=198$ $\mathrm{mAu}$ at $3.1 \mu \mathrm{g} / \mathrm{mL}$.

\section{Pig pulmonary tissue samples}

Lung samples (from eight piglets treated with linezolid for 72-96 h) and controls (pulmonary tissues from piglets without treatment) were collected. One sample was obtained $72 \mathrm{~h}$ after starting treatment with linezolid (spontaneous death) and $12 \mathrm{~h}$ from the last dose. All others were collected at euthanasia after $96 \mathrm{~h}$ of treatment, and $12 \mathrm{~h}$ after the last drug dose. All were cut in pieces of $\sim 0.5 \mathrm{~g}$ and immediately frozen at $-40^{\circ} \mathrm{C}$ until analysis.
Mean ( \pm standard deviation) minimum linezolid concentrations in lung tissue $(\mathrm{n}=8)$ were $11.0 \pm 5.1 \mathrm{mg} / \mathrm{L}$.

\section{Discussion}

A specific HPLC method with adequate specificity, sensitivity, precision and accuracy has been developed to measure linezolid in lung tissue. This method allows rapid determination of linezolid concentrations in pulmonary tissue, offering a highly simplistic approach to sample preparation. It is accurate, reproducible and specific for linezolid.

Several examples of extraction and quantitation of antibiotics in different tissues have been described in the literature. The majority of them are based on homogenization using a homogenator or sonication system as the best technique to extract the drug from the tissue (23-26). Afterwards, samples are centrifuged, washed by filter or solid phase extraction (SPE), evaporated and re-diluted in an 
Table 2 Results from the stability analysis of linezolid in lung tissue after three freeze $\left(-40^{\circ} \mathrm{C}\right)$ and thaw cycles.

\begin{tabular}{llll}
\hline Linezolid & $\begin{array}{l}\mathrm{A}_{\mathrm{LNZ}} / \mathrm{A}_{\text {Oflox }} \\
\text { at baseline }\end{array}$ & $\begin{array}{l}\mathrm{A}_{\mathrm{LNZ}} / \mathrm{A}_{\text {Oflox }} \\
\text { after } 3 \text { cycles }\end{array}$ & $\mathrm{p}$-Value \\
\hline $100 \mu \mathrm{g} / \mathrm{mL}$ & 2.18 & 2.17 & 0.29 \\
$25 \mu \mathrm{g} / \mathrm{mL}$ & 0.37 & 0.38 & 0.18 \\
$3.1 \mu \mathrm{g} / \mathrm{mL}$ & 0.05 & 0.05 & 0.56 \\
\hline
\end{tabular}

$\mathrm{A}_{\mathrm{LNZ}} / \mathrm{A}_{\mathrm{Oflox}}$, linezolid area/ofloxacin area; $\mathrm{p}<0.05$ to be significant.

Table 3 Results of stability of ofloxacin.

\begin{tabular}{ll}
\hline Time & $\begin{array}{l}\text { Ofloxacin area, } \\
\mathrm{mAu} \times \mathrm{s}\end{array}$ \\
\hline $0 \mathrm{~h}$ & 14,079 \\
$30 \mathrm{~min}$ & 14,271 \\
$1 \mathrm{~h}$ & 13,789 \\
$2 \mathrm{~h}$ & 13,846 \\
$2.5 \mathrm{~h}$ & 14,195 \\
$3 \mathrm{~h}$ & 14,027 \\
$3.5 \mathrm{~h}$ & $\mathrm{NA}^{\mathrm{a}}$ \\
$4 \mathrm{~h}$ & $\mathrm{NA}^{\mathrm{a}}$ \\
$24 \mathrm{~h}$ & $\mathrm{NA}^{\mathrm{a}}$ \\
\hline
\end{tabular}

${ }^{a} \mathrm{NA}$, not available. (Double peak).

appropriate mobile phase. With respect to linezolid, there are several HPLC methods that have been published in the literature for measuring this drug in serum or plasma (15, 27-30). However, there are only a few HPLC methods for measuring linezolid quantification in tissues. One is the procedure described by De Jesús et al. (31). They propose an HPLC technique in which $1 \mathrm{~g}$ of pulmonary tissue is homogenized in a buffer solution $\left[\left(\mathrm{KH}_{2} \mathrm{PO}_{4}, \mathrm{Na}_{2} \mathrm{HPO}_{4} \cdot 12 \mathrm{H}_{2} \mathrm{O}\right) /\right.$ $0.1 \%$ Triton $\mathrm{x}-100(\mathrm{pH} \mathrm{7.4)}$, centrifuged, and $100 \mu \mathrm{L}$ of supernatant is injected into the chromatographic system. In this method, the column temperature is maintained at $28^{\circ} \mathrm{C}$ under isocratic conditions. The quantitation limit is $0.25 \mathrm{mg} /$ $\mathrm{L}$ and imprecision is $<10 \%$. It is noteworthy to consider that these data are similar to our results given that, in our study, the LOD and LLOQ are $0.8 \mu \mathrm{g} / \mathrm{mL}$ and $1.56 \mu \mathrm{g} / \mathrm{mL}$, respectively. Also, the intra-day and inter-day precision is $<6.5 \%$ across the entire range of concentrations studied.

Our data are consistent with the results reported by Honeybourne et al. (11). They analyzed linezolid in several tissues including bone, fat and muscle, but not lung, by homogenizing the tissue with acetonitrile. Afterwards, these samples were centrifuged and the supernatant injected into the chromatographic system. The LLOQ is set at $0.1 \mathrm{mg} / \mathrm{L}$ and the intra-day and inter-day coefficient of variation was $<6.0 \%$ and $12.5 \%$, respectively. Our study using pulmonary tissue shows much better results than those reported previously. In our study, intra-day precision (five replicates at three different concentrations) is $<5.5 \%$ in all cases, and the inter-day precision (five replicates analyzed in three consecutive days) is $<6.5 \%$. In our study, the LLOQ was no $<1.56 \mu \mathrm{g} / \mathrm{mL}$. However, it should not have any impact in terms of clinical significance since this value is below the minimum inhibitory concentration of linezolid for MRSA.

Moreover, data from another study (32) which treated lung samples with a mixture of methanol/water (1:1) and lysing buffer, showed results similar to ours with respect to recovery values: $96 \%$ and $103 \%$ vs. $89.47 \%$ and $93.58 \%$ in our study.

Our data show lower minimum linezolid concentrations in pulmonary samples than those reported by Luna et al. (33). However, the lack of details on the methodology used to determine linezolid concentrations in pulmonary tissue in their study, and the fact that they used a different dose regimen $(300 \mathrm{mg} / 8 \mathrm{~h})$, makes it very difficult to compare both studies.

A possible limitation of the present study could be the clinical interpretation of the drug concentrations in homogenates related to antibiotic levels at the site of infection. Linezolid shows a low binding protein $(31 \%)$, and good penetration into skin, blister fluids, bone, muscle, fat, alveolar cells, lung extracellular lining fluid and cerebrospinal fluid $(2,34)$. It is well known that concentrations in tissue may depend on (i) the amount of blood in the tissue sample, (ii) chemical degradation of the drug during processing and (iii) sample collection. Blood present in the tissue or in its surface is included in the final homogenate. In order to reduce possible bias due to this fact, an adjustment by weight of the real analyzed portion of lung and the extracted volume after homogenation were both taken into account in this analysis. With respect to chemical degradation, calibration with IS (ofloxacin) was used to control any loss of specimen during the analysis. In addition to circumvent any artifact or loss of the drug during sample preparation, all standards were prepared in the appropriate tissue homogenate (lung homogenate). To avoid the drawback related to sample collection, all tissue samples were taken when the distribution phase of the drug had been completed and equilibrium between the vascular space and tissue was complete.

Homogenization implies disruption of cell membranes and mixing of both intracellular and extracellular fluids and solids. However, in this particular case a minor dilutional effect on linezolid concentration could be expected after tissue homogenization since the drug is distributed primarily in the extracellular space. However, one may hypothesize that linezolid concentrations in the biophase might be slightly higher than those observed following tissue homogenization.

The availability of an HPLC method to determine antibiotic concentrations, both in serum and lung, provides a unique opportunity to gain insight into relevant aspects regarding the clinical response to specific treatments. Studies in animal models of pneumonia, where it is possible to obtain lung tissue, offer an exceptional opportunity to learn about the pharmacokinetics and pharmacodynamics (PD) of antibiotics. The combination of PK and PD data might help to further implement optimal antibiotic dosing regimens in humans.

In conclusion, the HPLC assay we developed and reported in this study allows for fast, easy, reliable and cheap analysis of linezolid in pulmonary tissue. Linezolid analysis, per- 
formed using an isocratic mode, is completed within $12 \mathrm{~min}$. This method might be helpful to develop future pharmacokinetic studies of linezolid penetration in pulmonary tissue.

\section{Conflict of interest statement}

Authors' conflict of interest disclosure: The authors stated that there are no conflicts of interest regarding the publication of this article. Research funding played no role in the study design; in the collection, analysis, and interpretation of data; in the writing of the report; or in the decision to submit the report for publication.

Research funding: This study was funded by grants from Ciber de Enfermedades Respiratorioas (CibeRes, CB06/06/0028) from Instituto de Salud Carlos III (ISCIII), Fondo de Investigaciones Sanitarias (FIS) beca FIS PI070419, 2009 SGR-911 and HERACLES RD /06/0009/0008.

Employment or leadership: None declared.

Honorarium: None declared.

\section{References}

1. Perry CM, Jarvis B. Linezolid. A review of its use in the management of serious Gram-positive infections. Drugs 2001;61: $525-51$

2. MacGowan AP. Pharmacokinetic and pharmacodynamic profile of linezolid in healthy volunteers and patients with Gram-positive infections. J Antimicrob Chemother 2003;51:17-25.

3. Burkhardt O, Majcher-Peszynska J, Borner K, Mundkowski R, Drewelown B, Derendorf H, et al. Penetration of ertapenem into different pulmonary compartments of patients undergoing lung surgery. J Clin Pharmacol 2005;45:659-65.

4. Conte JE Jr, Golden JA, Kelly MG, Zurlinden E. Steady-state serum and intrapulmonary pharmacokinetics and pharmacodynamics of tigecycline. Int J Antimicrob Agents 2005;25:523-9.

5. Ong CT, Dandekar PK, Sutherland C, Nightingale CH, Nicolau DP. Intrapulmonary concentrations of telithromycin: clinical implications for respiratory tract infections due to Streptococcus pneumoniae. Chemotherapy 2005;51:339-46.

6. Mimoz O, Rolland D, Adoun M, Marchand S, Breilh D, Brumpt I, et al. Steady-state trough serum and epithelial lining fluid concentrations of teicoplanin $12 \mathrm{mg} / \mathrm{kg}$ per day in patients with ventilator-associated pneumonia. Intens Care Med 2006;32:775-9.

7. Lamer C, de Beco V, Soler P, Calvat S, Fagon JY, Dombret $\mathrm{MC}$, et al. Analysis of vancomycin entry into pulmonary lining fluid by bronchoalveolar lavage in critically ill patients. Antimicrob Agents Chemother 1993;37:281-6.

8. Baldwin DR. The penetration of novel intravenous cephalosporins into the lung. J Chemother 1996;8:71-82.

9. Georges B, Conil JM, Cougot P, Decun JF, Archambaud M, Seguin T, et al. Cefepime in critically ill patients: continuous infusion vs. an intermittent dosing regimen. Int J Clin Pharmacol Ther 2005;43:360-9.

10. Panidis D, Markantonis SL, Boutzouka E, Karatzas S, Baltopoulos G. Penetration of gentamicin into the alveolar lining fluid of critically ill patients with ventilator-associated pneumonia. Chest 2005;128:545-52.

11. Honeybourne D, Tobin C, Jevons G, Andrews J, Wise R. Intrapulmonary penetration of linezolid. J Antimicrob Chemother 2003;51:1431-4.
12. Jehl F, Gallion C, Monteil H. High-performance liquid chromatography of antibiotics. J Chromatogr 1990;531:509-49.

13. Skoog D, Holler FJ, Nieman TA. Principios de Analisis Instrumental, 5th ed. Madrid: The McGraw-Hill Company; 2001.

14. Meyer V. Practical high-performance liquid chromatography, 4th ed. Switzerland: John Wiley \& Sons Ltd, 2004.

15. Tobin CM, Sunderland J, White LO, MacGowan AP. A simple isocratic high-performance liquid chromatography assay for linezolid in human serum. J Antimicrob Chemother 2001;48: 605-8.

16. Nix D, Goodwin D, Peloquin Ch, Rotella D, Schentag J. Antibiotic tissue penetration and its relevance: models of tissue penetration and their meaning. J Antimicrob Agents Chemother 1991;35:1947-52.

17. Department of Health and Human Services Food and Drug Administration (U.S.). URL: http://www.fda.gov/cder/guidance/ 4252fnl.pdf. Accessed May 7, 2009. http://www.fda.gov/cder/ guidance/cmc3.pdf. Accessed May 7, 2009. http://www.fda. gov/cber/gdlns/methval.pdf. Accessed May 7, 2009.

18. The European Agency for the Evaluation of Medicinal Products (Europe). URL: http://www.emea.europa.eu/htms/vet/vetguidelines/quality.htm. Accessed May 7, 2009. http://www.emea. europa.eu/pdfs/human/ich/038195en.pdf. Accessed May 7, 2009.

19. Lang JR, Bolton S. A comprehensive method validation strategy for bioanalytical applications in the pharmaceutical industry. J Pharm Biomed Anal 1991;5:361-75.

20. Christodoulou EA, Samanidou VF, Papadoyannis IN. Validation of an HPLC-UV method according to the European Union Decision 2002/657/EC for the simultaneous determination of 10 quinolones in chicken muscle and egg yolk. J Chromatogr 2007;857:246-55.

21. Samanidou VF, Nisyriou SA, Papadoyannis IN. Development and validation of an HPLC method for the determination of penicillin antibiotics residues in bovine muscle according to the European Union Decision 2002/657/EC. J Sep Sci 2007;30: 3193-201.

22. Luna CM, Sibila O, Agustí C, Torres A. Animal models of ventilator associated pneumonia [review]. Eur J Respir 2009; $33: 182-8$.

23. Trittler R, Ehrlich M, Galla TJ, Horch RE, Kümmerer KJ. New and rapid fully automated method for determination of tazobactam and piperacillin in fatty tissue and serum by columnswitching liquid chromatography. J Chromatogra B 2002; 775:127-32.

24. Lifschitz A, Virkel G, Imperiale F, Sutra JF, Galtier P, Lanusse $\mathrm{C}$, et al. Moxidectin in cattle: correlation between plasma and target tissues disposition. J Vet Pharmacol Therap 1999;22: 266-73.

25. Alvinerie M, Sutra JF, Capela D, Galtier P, Fernandez-Suarez A, Horne E, et al. Matrix solid-phase dispersion technique for the determination of moxidectin in bovine tissues. M Analyst 1996;121:1469-72.

26. Nave R, Fisher R, McCracken N. In vitro metabolism of beclomethasone dipropionate, budesonide, ciclesonide, and fluticasone propionate in human lung precision-cut tissue slices. Respir Res 2007;8:65-74.

27. Ehrlich M, Trittler R, Daschner FD, Kümmerer KJ. A new and rapid method for monitoring the new oxazolidinone antibiotic linezolid in serum and urine by high performance liquid chromatography-integrated sample preparation. Chromatogr B Biomed Sci Appl 2001;755:373-7.

28. Boak LM, Li J, Nation RL, Rayner CR. High-performance liq- 
uid chromatographic method for simple and rapid determination of linezolid in human plasma. Biomed Chromatogr 2006;20: $782-6$.

29. Kitahashi T, Futura I. Method development for determining the antibacterial linezolid in human serum by micellar electrokinetic capillary chromatography. J Pham Biomed Anal 2002; 30:1411-6.

30. Peng GW, Stryd RP, Murata S, Igarashi M, Chiba K, Aoyama $\mathrm{H}$, et al. Determination of linezolid in plasma by reversed-phase high-performance liquid chromatography. J Pharm Biomed Anal 1999;20:65-73.

31. De Jesús MJ, Salamanca N, Gonzalez F, Dominguez-Gil A, Sanchez A. Disposition of linezolid in the isolated rat lung after systemic and pulmonary drug delivery. J Antimicrob Chemother 2007;60:1074-9.

32. Shaikh ZH, Peloquin Ch, Ericsson Ch. Successful treatment of vancomycin-resistant enterococcus faecium meningitis with linezolid: case report and literature review. Scand J Infect Dis 2001;33:375-9.

33. Luna CM, Bruno DA, García-Morato J, Mann KC, Risso Patrón J, Sagardía J, et al. Effect of linezolid compared with glycopeptides in methicillin-resistant Staphylococcus aureus severe pneumonia in piglets. Chest 2009;135:1564-71.

34. Gee T, Ellis R, Marshall G, Andrews J, Ashby J, Wise R. Pharmacokinetics and tissue penetration of linezolid following multiple oral doses. J Antimicrob Chemother 2001;45:1843-6. 